\title{
Dynamic Regulation of Extracellular Superoxide Production by the Coccolithophore Emiliania huxleyi (CCMP 374)
}

OPEN ACCESS

Edited by:

Ondrej Prasil,

Institute of Microbiology (ASCR),

Czechia

Reviewed by:

Allen Milligan,

Oregon State University,

United States

Gustaaf Marinus Hallegraeff,

University of Tasmania,

Australia

${ }^{*}$ Correspondence: Julia M. Diaz

j2diaz@ucsd.edu;

julia.diaz@skio.uga.edu

${ }^{\dagger}$ Present address:

Sydney Plummer,

Scripps Institution of Oceanography, University of California San Diego,

La Jolla, CA, United States

Julia M. Diaz,

Scripps Institution of Oceanography, University of California San Diego,

La Jolla, CA, United States

Specialty section:

This article was submitted to

Aquatic Microbiology

a section of the journal

Frontiers in Microbiology

Received: 25 February 2019 Accepted: 20 June 2019

Published: 12 July 2019

Citation:

Plummer S, Taylor AE, Harvey EL, Hansel CM and Diaz JM (2019)

Dynamic Regulation of Extracellular Superoxide Production by the Coccolithophore

Emiliania huxleyi (CCMP 374).

Front. Microbiol. 10:1546.

doi: 10.3389/fmicb.2019.01546

\author{
Sydney Plummer ${ }^{1 \dagger}$, Alexander E. Taylor ${ }^{2}$, Elizabeth L. Harvey ${ }^{1}$, Colleen M. Hansel ${ }^{3}$ and \\ Julia M. Diaz ${ }^{1 * \dagger}$
}

'Department of Marine Sciences, Skidaway Institute of Oceanography, University of Georgia, Savannah, GA, United States, ${ }^{2}$ Department of Chemistry, University of Vermont, Burlington, VT, United States, ${ }^{3}$ Department of Marine Chemistry and Geochemistry, Woods Hole Oceanographic Institution, Woods Hole, MA, United States

In marine waters, ubiquitous reactive oxygen species (ROS) drive biogeochemical cycling of metals and carbon. Marine phytoplankton produce the ROS superoxide $\left(\mathrm{O}_{2}^{-}\right)$extracellularly and can be a dominant source of $\mathrm{O}_{2}^{-}$in natural aquatic systems. However, the cellular regulation, biological functioning, and broader ecological impacts of extracellular $\mathrm{O}_{2}^{-}$ production by marine phytoplankton remain mysterious. Here, we explored the regulation and potential roles of extracellular $\mathrm{O}_{2}^{-}$production by a noncalcifying strain of the cosmopolitan coccolithophorid Emiliania huxleyi, a key species of marine phytoplankton that has not been examined for extracellular $\mathrm{O}_{2}^{-}$production previously. Cell-normalized extracellular $\mathrm{O}_{2}^{-}$production was the highest under presumably low-stress conditions during active proliferation and inversely related to cell density during exponential growth phase. Removal of extracellular $\mathrm{O}_{2}^{-}$through addition of the $\mathrm{O}_{2}^{-}$scavenger superoxide dismutase (SOD), however, increased growth rates, growth yields, cell biovolume, and photosynthetic efficiency $\left(F_{v} / F_{m}\right)$ indicating an overall physiological improvement. Thus, the presence of extracellular $\mathrm{O}_{2}^{-}$does not directly stimulate $E$. huxleyi proliferation, as previously suggested for other phytoplankton, bacteria, fungi, and protists. Extracellular $\mathrm{O}_{2}^{-}$production decreased in the dark, suggesting a connection with photosynthetic processes. Taken together, the tight regulation of this stress independent production of extracellular $\mathrm{O}_{2}^{-}$by $E$. huxleyi suggests that it could be involved in fundamental photophysiological processes.

Keywords: reactive oxygen species, superoxide, Emiliania huxleyi, photophysiology, oxidative stress, redox homeostasis, biogeochemical cycling

\section{INTRODUCTION}

Ubiquitous reactive oxygen species (ROS) within marine waters help drive global biogeochemical cycling. ROS include intermediates in the reduction of molecular oxygen $\left(\mathrm{O}_{2}\right)$ to water $\left(\mathrm{H}_{2} \mathrm{O}\right)$, which consist of superoxide $\left(\mathrm{O}_{2}^{-}\right)$, hydrogen peroxide $\left(\mathrm{H}_{2} \mathrm{O}_{2}\right)$, and hydroxyl radical $(\mathrm{OH} \bullet)$. These ROS shape the transformation of metal nutrients including iron (Rose, 2012) and manganese (Wuttig et al., 2013), as well as carbon (Heller and Croot, 2010b) due to 
their ability to act as both oxidants and reductants. Within aquatic environments, ROS are produced through both abiotic (e.g., via photodegradation of organic matter) and biotic means (Zinser, 2018). Biotic mechanisms include active extracellular production by marine microorganisms, which can be a dominant source of $\mathrm{O}_{2}^{-}$in natural waters (Rose et al., 2008; Hansard et al., 2010).

While ROS are formed intracellularly within all aerobic organisms as metabolic by-products, a plethora of marine microorganisms actively produce ROS extracellularly as well. Although intracellular $\mathrm{O}_{2}^{-}$can be released into the marine environment upon cell lysis, these rates cannot account for the steady-state concentrations that have been measured in natural waters (Rose, 2012). Furthermore, within cells, $\mathrm{O}_{2}^{-}$ exists in equilibrium with its conjugate acid, the hydroperoxyl radical (HOO•); however, with a $\mathrm{pK}_{\mathrm{a}}$ of 4.8 , the $\mathrm{O}_{2}^{-}$anion is the dominant form at physiological pH (Bielski et al., 1985). Unlike $\mathrm{H}_{2} \mathrm{O}_{2}, \mathrm{O}_{2}^{-}$cannot readily diffuse across membranes due to its negative charge, short lifetime $\left(\sim 10^{-5} \mathrm{~s}\right)$, and limited diffusive distance $\left(\sim 10^{-7} \mathrm{~m}\right)$ (Lesser, 2006; Brown and Griendling, 2009; Diaz and Plummer, 2018). Thus, the majority of microbially derived $\mathrm{O}_{2}^{-}$within the extracellular environment must be created on or near the cell surface via active extracellular $\mathrm{O}_{2}^{-}$ production mechanisms (Diaz and Plummer, 2018).

The ability to produce extracellular $\mathrm{O}_{2}^{-}$has been documented among heterotrophic bacteria (Diaz et al., 2013) and phytoplankton, including cyanobacteria (Rose et al., 2005, 2008; Godrant et al., 2009; Hansel et al., 2016), diatoms (Kustka et al., 2005; Hansel et al., 2016; Schneider et al., 2016), dinoflagellates (Saragosti et al., 2010; Zhang et al., 2016a), nontoxic microalgae (Marshall et al., 2005a), and harmful microalgae (Oda et al., 1997; Marshall et al., 2005a,b; Portune et al., 2010; Diaz and Plummer, 2018). Despite advancements in identifying the extensive presence and environmental relevance of extracellular $\mathrm{O}_{2}^{-}$production by marine microflora, the mechanisms of extracellular $\mathrm{O}_{2}^{-}$ production and its biological roles are not well understood. The freshwater chlorophyte Chlamydomonas reinhardtii (Anderson et al., 2015) and marine raphidophytes Chattonella marina and Chattonella ovata (Kim et al., 2000, 2007) are either confirmed or thought to produce extracellular $\mathrm{O}_{2}^{-}$via cell membrane associated enzymes known as NADPH oxidases (Nox). These enzymes transfer electrons from cytosolic NADPH pools across cell membranes to reduce $\mathrm{O}_{2}$ in the surrounding aqueous environment, thus creating extracellular $\mathrm{O}_{2}^{-}$. The presence of these enzymes has been implicated in diatoms and dinoflagellates as well (Kim et al., 2000; Kustka et al., 2005; Hervé et al., 2006; Saragosti et al., 2010). Extracellular $\mathrm{O}_{2}^{-}$production is light dependent in several phytoplankton taxa (Kim et al., 1999; Marshall et al., 2002; Milne et al., 2009; Saragosti et al., 2010; Hansel et al., 2016; Schneider et al., 2016), which has led to speculation that photosynthesis may serve an indirect role in extracellular $\mathrm{O}_{2}^{-}$production by supplying NADPH to cell surfaceassociated NADPH-oxidizing enzymes such as Nox (Marshall et al., 2002; Saragosti et al., 2010; Schneider et al., 2016).

Proposed biological roles of phytoplankton-derived extracellular $\mathrm{O}_{2}^{-}$are diverse (Diaz and Plummer, 2018). For instance, extracellular $\mathrm{O}_{2}^{-}$production has been implicated in harmful algal bloom toxicity (Tanaka et al., 1992; Yang et al., 1995; Kim et al., 1999; Marshall et al., 2003; Kim and Oda, 2010; Dorantes-Aranda et al., 2013, 2015; Mardones et al., 2015), metal nutrient acquisition (Rose et al., 2005; Garg et al., 2007; Liu et al., 2007; Rose, 2012; Roe and Barbeau, 2014), allelopathy (Oda et al., 1992, 1997; Marshall et al., 2005b), and defense against grazing (Martel, 2009; Flores et al., 2012). Model phytoplankton species generate abundant extracellular $\mathrm{O}_{2}^{-}$ even under ideal growth conditions in the absence of any obvious stressors (Kustka et al., 2005; Rose et al., 2005; Marshall et al., 2005a,b; Godrant et al., 2009; Portune et al., 2010; Diaz et al., 2013; Hansel et al., 2016; Schneider et al., 2016), suggesting an association with basal functioning. For example, extracellular $\mathrm{O}_{2}^{-}$regulates growth and morphology in the prolific ROS producer, C. marina (Oda et al., 1995), as well as growth in bacteria (Saran, 2003; Hansel et al., 2019) and differentiation in microbial eukaryotes (Aguirre et al., 2005). In these microorganisms, extracellular $\mathrm{O}_{2}^{-}$production rates are the highest during active growth and at low cell densities consistent with beneficial cell signaling and autocrine growth regulation, as also seen in plants (Mittler et al., 2011) and animals (Brown and Griendling, 2009; Aguirre and Lambeth, 2010). The accumulation of studies showing that extracellular $\mathrm{O}_{2}^{-}$ production by diverse phytoplankton is similarly dependent on cell density (Marshall et al., 2005a; Hansel et al., 2016; Diaz et al., 2018) and growth phase (Oda et al., 1995; Kim et al., 1999; Portune et al., 2010) has spurred speculation that extracellular $\mathrm{O}_{2}^{-}$production may be involved in phytoplankton cell signaling and/or growth regulation in species other than C. marina, although this possibility remains largely untested (Hansel et al., 2016; Diaz and Plummer, 2018).

Clarifying the cellular regulation and biological function of active extracellular $\mathrm{O}_{2}^{-}$production by phytoplankton is critical to understand the effects of ROS on ocean redox balance, biogeochemical cycling, and ecological interactions in marine waters. Among phytoplankton, coccolithophores are one of the most prevalent groups in the global ocean. Further, the original report of extracellular $\mathrm{H}_{2} \mathrm{O}_{2}$ production by the coccolithophorid species Pleurochrysis carterae pioneered the recognition of microorganisms as significant sources of ROS in aquatic systems (Palenik et al., 1987). Despite this discovery, however, coccolithophorids are under explored in terms of extracellular ROS production. Therefore, this study was conducted to investigate the dynamics, cellular regulation, and biological function of extracellular $\mathrm{O}_{2}^{-}$production by a noncalcifying strain of Emiliania huxleyi (CCMP 374), the most prevalent coccolithophore species in modern oceans (Westbroek et al., 1989; Brown and Yoder, 1994).

\section{MATERIALS AND METHODS}

\section{Cultivation of E. huxleyi, Growth Tracking, and Cell Counts}

Axenic cultures of E. huxleyi CCMP 374 were obtained from the National Center for Marine Algae and Microbiota (NCMA) at Bigelow Laboratory for Ocean Sciences (East Boothbay, ME). 
Cultures of E. huxleyi were inoculated into $\mathrm{f} / 2$ growth media prepared without the addition of silicic acid (Guillard and Ryther, 1962) using $0.2 \mu \mathrm{m}$ filtered natural seawater collected from the South Atlantic Bight. Media were prepared and autoclaved $\left(121^{\circ} \mathrm{C}, 20 \mathrm{~min}\right)$ at least 1 day prior to inoculating cultures. Cultures were begun with exponential phase inocula, unless otherwise stated. Cultures were either grown in borosilicate culture tubes with caps or Erlenmeyer flasks of various sizes with aluminum foil or an acid washed plastic beaker covering the mouth of the flask at $18^{\circ} \mathrm{C}$ under cool, white light $(\sim 130 \mu \mathrm{mol}$ photons $\mathrm{m}^{-2} \mathrm{~s}^{-1}$, 14:10 light dark cycle). Growth was monitored by observing in vivo chlorophyll fluorescence using an AquaFluor $^{\circledR}$ handheld fluorometer (Turner Designs, San Jose, $\mathrm{CA}$ ) or a $10-\mathrm{AU}^{\mathrm{TM}}$ fluorometer (Turner Designs, San Jose, CA). In vivo fluorescence values were normalized to measurements taken on day 0. Exponential growth phase was defined as the log-linear portion of the in vivo fluorescence data versus time ( $R^{2} \geq 0.98$ in all cultures). Stationary phase was determined to be the time between the end of the log linear portion of the growth curve and until the end of the growth curve. Specific growth rates during exponential growth phase were found by calculating the slope of the regression of the natural log-normalized in vivo fluorescence versus time. Culture $\mathrm{pH}$ was monitored using an Accumet AB 15/15+ pH meter (Thermo Fisher Scientific, Waltham, MA) in cultures grown from stationary phase inocula in $25 \mathrm{~mm}$ borosilicate tubes (Thermo Fisher Scientific, 14-961-34). E. huxleyi cell abundances (cells $\mathrm{ml}^{-1}$ ) were obtained using a Guava ${ }^{\circledR}$ easyCyte flow cytometer (Millipore Sigma, Merck KGaA, Dermstadt, Germany) and analyzed with Guava InCyte ${ }^{\mathrm{TM}} 3.1$ software. Flow cytometry samples were preserved with a final concentration of $0.5 \%$ glutaraldehyde, as well as $1 \%$ peptone to prevent cell adsorption to sample tubes. Flow cytometry samples were stored at $-80^{\circ} \mathrm{C}$ prior to processing. To process samples, 50-200 $\mu \mathrm{l}$ of each sample was pipetted into 96-well plates, diluted with filtered seawater as needed, and run at a low flow rate $\left(0.24 \mu \mathrm{l} \mathrm{s}^{-1}\right)$ for $3 \mathrm{~min}$. For analysis, concentrations of healthy cell populations (cells $\mathrm{ml}^{-1}$ ) were determined based on gates of red fluorescence and forward scatter signals from previously run samples of exponentially growing cultures.

In two separate experiments, extracellular $\mathrm{O}_{2}^{-}$was removed from E. huxleyi cultures by adding superoxide dismutase (SOD, Millipore Sigma 574,594-50KU), an enzyme that specifically degrades $\mathrm{O}_{2}^{-}$. To begin this experiment, $7.5 \mathrm{ml}$ of media were inoculated with $300 \mu \mathrm{l}$ stationary phase culture to give an initial concentration of $\sim 2.3 \times 10^{5}$ cells $\mathrm{ml}^{-1}$ and grown under the conditions above in $13 \mathrm{~mm}$ borosilicate glass tubes (Thermo Fisher Scientific, 14-962-26D). Treatments included three different concentrations of SOD added at three different volumes and a deionized water (DI) control. A $10 \mathrm{kU} \mathrm{ml}^{-1}$ stock of SOD was prepared using DI. Then, treatments were performed on triplicate cultures, where each tube received daily additions of $20.25 \mu \mathrm{l}, 37.5 \mu \mathrm{l}$, or $75 \mu \mathrm{l}$ of the $10 \mathrm{kU} \mathrm{ml}^{-1}$ SOD stock, or $75 \mu \mathrm{l}$ DI to give final concentrations of $27 \mathrm{U} \mathrm{ml}^{-1} \mathrm{SOD}$, $50 \mathrm{U} \mathrm{ml}^{-1} \mathrm{SOD}, 100 \mathrm{U} \mathrm{ml}^{-1} \mathrm{SOD}$, or $0 \mathrm{U} \mathrm{ml}^{-1} \mathrm{SOD}$, respectively. A subsequent control experiment was performed with diafiltered SOD to ensure that SOD was responsible for potential changes observed in the cultures. For this control experiment, $7.5 \mathrm{ml}$ of media were inoculated with $300 \mu \mathrm{l}$ stationary phase culture to give an initial concentration of $\sim 1.8 \times 10^{5}$ cells $\mathrm{ml}^{-1}$ and grown under the conditions above in $13 \mathrm{~mm}$ borosilicate glass tubes. To create the dialyzed SOD, a $10 \mathrm{kU} \mathrm{ml}^{-1}$ SOD stock prepared with DI was diafiltered by passing the SOD solution through an Amicon ultrafiltration device $(10 \mathrm{kDa}$ molecular weight cut-off, Millipore) at $3200 \times g$ for $20 \mathrm{~min}$ at $4^{\circ} \mathrm{C}$, thereby removing the enzyme from the solution. Treatments were performed on triplicate cultures, where each tube received daily additions of $75 \mu \mathrm{l}$ dialyzed SOD, $75 \mu \mathrm{l} \mathrm{DI}$, and $75 \mu \mathrm{l} \mathrm{SOD}$ (100 $\mathrm{U} \mathrm{ml}^{-1}$ SOD final concentration).

\section{Cell Imaging and Analysis}

Individual E. huxleyi cells were imaged using a FlowCam ${ }^{\circledR}$ (Fluid Imaging Inc., Scarborough, ME), a continuous flowthrough microscope fitted with a color and monochromatic camera. To calibrate the FlowCam ${ }^{\circledR}$ for imaging, dilutions of E. huxleyi cultures from 0 to $95 \%$ using $0.2 \mu \mathrm{m}$ filtered seawater were analyzed in varying context settings. Final settings (Supplementary Table S1) were chosen based on their ability to differentiate cell shape and color and provide useable images for morphological and volume assessments. Culture samples of $100 \mu \mathrm{l}$ were diluted with $500 \mu \mathrm{l}$ of $0.2 \mu \mathrm{m}$ filtered seawater prior to analysis on the FlowCam ${ }^{\circledR}$. Images were analyzed with VisualSpreadsheet ${ }^{\circledR}$ (Fluid Imaging Inc., Scarborough, ME). The spherical biovolume was determined using three separate measurements of cell diameter. The FlowCam ${ }^{\circledR}$ software calculates three different diameters for each cell image [area based diameter $(\mathrm{ABD})$, equivalent spherical diameter (ESD), filled or full diameter (FD)], thus giving three alternative biovolume assessments for every imaged cell. Further analysis and filtering of FlowCam ${ }^{\circledR}$ images as well as details on diameter calculations are described in the Supplementary Material.

\section{Photophysiology}

Photophysiological health of E. huxleyi was monitored using the Satlantic fluorescence induction and relaxation (FIRe) fluorometer system (Sea-bird Scientific, Halifax, NS Canada). Prior to analysis, samples were allowed to dark adapt for approximately $30 \mathrm{~min}$ and were then diluted using $0.2 \mu \mathrm{m}$ filtered seawater as necessary to avoid detector saturation. Samples were illuminated with a single turnover flash of blue excitation for a duration of $80 \mu \mathrm{s}$. The measured fluorescence response was used to calculate the maximum efficiency of photosystem II (PSII), or $F_{v} / F_{m}$, using the equation:

$$
F_{v} / F_{m}=\frac{\left(F_{m}-F_{o}\right)}{F_{m}}
$$

where $F_{m}$ is the maximum fluorescence yield, and $F_{o}$ is the minimum fluorescence yield. For each sample, 20 acquisitions were obtained.

\section{Extracellular $\mathrm{O}_{2}^{-}$Production}

Net extracellular $\mathrm{O}_{2}^{-}$production by E. huxleyi was measured using the flow-through FeLume (II) analytical system 
(Waterville Analytical, Waterville, ME) by detecting chemiluminescence emitted through the reaction of $\mathrm{O}_{2}^{-}$ and the specific probe methyl Cypridina luciferin analog (MCLA), as previously described (Diaz et al., 2013; Schneider et al., 2016). This method allows for manipulation of experimental settings (e.g., light levels, increasing cell density) during analysis to detect changes in $\mathrm{O}_{2}^{-}$on immediate timescales (i.e., seconds). It has been used to measure $\mathrm{O}_{2}^{-}$ production in pure cultures (Kustka et al., 2005; Diaz et al., 2013; Schneider et al., 2016; Zhang et al., 2016a; Hansel et al., 2019) and natural waters (Diaz et al., 2016; Hansel et al., 2016; Zhang et al., 2016b). Following the procedures of Diaz et al. (2013), MCLA blanks generated in the absence of SOD were used to determine biologically derived $\mathrm{O}_{2}^{-}$ concentrations, in order to avoid overestimation of biological $\mathrm{O}_{2}^{-}$production rates due to MCLA auto-oxidation. Briefly, cells were deposited onto an inline filter $(0.22 \mu \mathrm{m})$, continuously rinsed $\left(2 \mathrm{ml} \mathrm{min}^{-1}\right)$ with a phosphate buffer $(20 \mathrm{mM} ; \mathrm{pH}=7.6)$ that matched the salinity of the seawater media base ( $38 \mathrm{psu}$ ), and $\mathrm{O}_{2}^{-}$was quantified in the cell-free effluent upon reaction with the MCLA reagent [4 $\mu \mathrm{M}$ MCLA, 0.1 M MES, $75 \mu \mathrm{M}$ diethylenetriamine pentaacetic acid (DTPA), $\mathrm{pH}=6$ ] in a spiral flow cell adjacent to a photomultiplier tube. Chemiluminescent signals from the phosphate buffer and MCLA baselines as well as biological samples were allowed to stabilize $(\leq 4 \% \mathrm{CV})$ for at least $1 \mathrm{~min}$, allowing calculation of a steady-state $\mathrm{O}_{2}^{-}$ concentration. In this way, obtaining a stable chemiluminescent signal from the MCLA reacting with effluent from biological samples demonstrated that the $\mathrm{O}_{2}^{-}$being detected was not a rapid, short-lived release of intracellular $\mathrm{O}_{2}^{-}$due to cell rupture. SOD was added at the end of each analysis (final concentration of $\sim 800 \mathrm{U} \mathrm{l}^{-1}$ ) to confirm the signal acquired on the FeLume (II) system was due to $\mathrm{O}_{2}^{-}$. In comparison to the aforementioned study by Diaz et al. (2013), the following exceptions were implemented here. First, cells deposited on the filter were exposed to ambient light $(\sim 5 \mu \mathrm{mol}$ photons $\mathrm{m}^{-2} \mathrm{~s}^{-1}$ ) unless they were covered in a dark photography film-changing bag to obtain dark $(0 \mu \mathrm{mol}$ photons $\mathrm{m}^{-2} \mathrm{~s}^{-1}$ ) measurements, as indicated. Second, only net production rates were determined, and finally, calibration was performed using standard additions of potassium superoxide $\left(\mathrm{KO}_{2}\right)$ by the method of Schneider et al. (2016). A preliminary cell concentration was obtained by microscopy using a hemocytometer counting chamber to help ensure that the same number of cells was loaded onto the in-line filter from each biological replicate and on each day within an experiment. The biotic steady-state $\mathrm{O}_{2}^{-}$concentration was calculated by subtracting blank signals generated from the mixture of MCLA and phosphate buffer with a syringe filter inline and in the absence of SOD. Then, net $\mathrm{O}_{2}^{-}$ production rates were calculated by multiplying the biotic steady-state $\mathrm{O}_{2}^{-}$concentration $(\mathrm{pM})$ by the flow rate $\left(2 \mathrm{ml} \mathrm{min}{ }^{-1}\right)$, dividing that value by the number of cells loaded onto the inline filter (either found using microscopy or flow cytometry), and converting to final units of amol cell ${ }^{-1} \mathrm{~h}^{-1}$. All chemicals used to measure $\mathrm{O}_{2}^{-}$were obtained from Millipore Sigma, except for MCLA, which was obtained from Tokyo Chemical Industry Co., Ltd.

\section{Statistical Analyses}

All statistical analyses were performed using JMP Pro 13.0.0 (SAS Institute Inc., Cary, NC). Regression analyses of cellnormalized $\mathrm{O}_{2}^{-}$production rates as a function of time across the growth curve of E. huxleyi and cell density were performed using Spearman's rank-order correlation. This regression analysis indicates the presence or absence of monotonic relationships based on the correlation coefficient $(\rho)$ and its level of significance $(p)$. An independent two sample Student's $t$-test was used to determine potential differences between mean $F_{v} / F_{m}$ values measured on various days throughout the growth curve of E. huxleyi. To determine the effect of SOD additions on in vivo fluorescence, a mixed factor repeated measures ANOVA was used. To determine the effect of dilution on per-cell $\mathrm{O}_{2}^{-}$production and the effect of SOD addition on growth rates, cell abundances, cell biovolume, and $F_{v} / F_{m}$ values, a comparison of means using an independent two sample Student's $t$-test was employed for each parameter interrogated. A one-sample Student's $t$-test was used to determine the potential difference between E. huxleyi $\mathrm{O}_{2}^{-}$production in the presence and absence of light. For all statistical analyses, the significance threshold (alpha) was set to 0.05 .

\section{RESULTS}

\section{Extracellular $\mathrm{O}_{2}^{-}$Production as a Function of Growth Phase}

To assess per-cell extracellular $\mathrm{O}_{2}^{-}$modulation across different average metabolic states, cell-normalized extracellular $\mathrm{O}_{2}^{-}$ production by E. huxleyi was measured throughout the growth curve of batch cultures. To rule out potential cell density effects, the number of cells analyzed at each time point was kept constant [average \pm SE was $8.32 \times 10^{5} \pm 5.98 \times 10^{4}$ cells $(n=30)$ ]. The highest per-cell net extracellular $\mathrm{O}_{2}^{-}$production rates were observed during early exponential growth when $F_{v} / F_{m}$ values were the highest (Supplementary Figure S1) and significantly declined as E. huxleyi grew over time (Spearman's $\rho=-0.58 ; p<0.0001$ ) (Figure 1). For example, E. huxleyi produced maximum amounts of $\mathrm{O}_{2}^{-}$(average $\pm \mathrm{SE}$ ) at the first time point measured in early exponential phase $(4,478 \pm 611$ amol cell ${ }^{-1} \mathrm{~h}^{-1}, n=3$; day 2 ). These maximal rates were nearly 78 times higher than net production rates measured between day 8 and day 25, when average production declined to $58 \pm 55$ amol cell ${ }^{-1} \mathrm{~h}^{-1}(n=30)$. Flow cytometry analyses revealed this decline was not due to an increase in senescent cells (i.e., cells with low chlorophyll). After day 8, net cell-normalized $\mathrm{O}_{2}^{-}$ production rates were occasionally negative, fluctuating between $-253 \pm 167$ (day 22; $n=3$ ) and $209 \pm 360$ (day 17; $n=3)$. Net per-cell $\mathrm{O}_{2}^{-}$production rates account for the simultaneous production and decay of $\mathrm{O}_{2}^{-}$at the cell surface. Because auto-oxidation of the MCLA probe results in a small amount of $\mathrm{O}_{2}^{-}$production (Fujimori et al., 1993), the negative net per-cell $\mathrm{O}_{2}^{-}$production rates between day 8 and day 25 reflect degradation of $\mathrm{O}_{2}^{-}$originating from the MCLA reagent. 


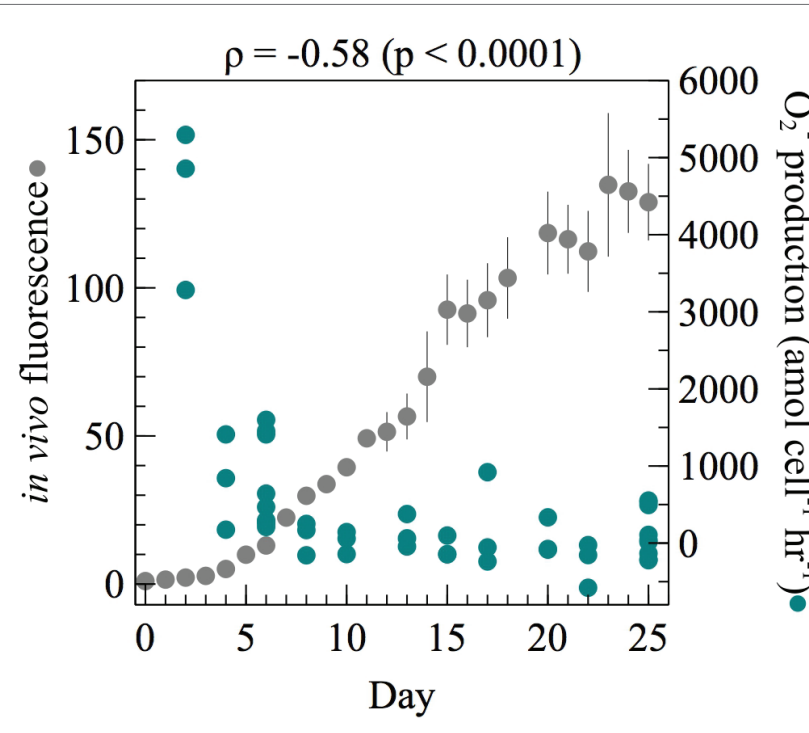

FIGURE 1 | At each time point throughout the growth curve of E. huxleyi, net per-cell $\mathrm{O}_{2}^{-}$production rates were measured from $\sim 10^{6}$ cells $(n=3$ biological replicates for each day except day 6 and day 25 where three separate measurements were made on three biological replicates giving $n=9$ ). Regression analysis on per-cell $\mathrm{O}_{2}^{-}$production as a function of time was performed using Spearman's rank-order correlation. The correlation coefficient $(\rho)$ and its level of significance $(p)$ are provided. In vivo fluorescence was normalized to the value on day 0 . Error bars indicate one standard error of the mean of three biological replicates.

\section{Extracellular $\mathrm{O}_{2}^{-}$Production as a Function of Cell Density}

Two approaches were undertaken to determine the potential effect of cell density on extracellular $\mathrm{O}_{2}^{-}$production. First, short-term effects (sec-min) were tested by measuring cellnormalized $\mathrm{O}_{2}^{-}$production rates and total $\mathrm{O}_{2}^{-}$concentrations while increasing the number of cells loaded on the FeLume filter in both exponential and stationary growth phase. The total $\mathrm{O}_{2}^{-}$concentration increased significantly with increasing cell density during both exponential (Spearman's $\rho=0.92$; $p<0.0001$ ) and stationary phase (Spearman's $\rho=0.89$; $p<0.0001)$. Conversely, net per-cell $\mathrm{O}_{2}^{-}$production rates decreased significantly with increasing cell density during exponential phase (Spearman's $\rho=-0.74 ; p<0.001$ ) but not during stationary phase (Spearman's $\rho=-0.20 ; p=0.45$ ) (Figure 2). In exponential phase, average net per-cell $\mathrm{O}_{2}^{-}$ production rates decreased by more than $200 \%$ from the highest $\left(9.2 \times 10^{6}\right)$ to lowest $\left(4.6 \times 10^{5}\right)$ number of cells analyzed.

To assess longer-term effects (min-h) of cell density on extracellular $\mathrm{O}_{2}^{-}$production, exponentially growing cells were preconditioned to lower cell densities by diluting cultures with $0.22 \mu \mathrm{m}$ filtered, autoclaved seawater and incubating for $0-6.5 \mathrm{~h}$ prior to conducting $\mathrm{O}_{2}^{-}$measurements. In this experiment, the number of cells loaded on the FeLume filter at each dilution level was kept constant [average \pm SE was $1.32 \times 10^{6} \pm 8.47 \times 10^{4}$ cells $\left.(n=26)\right]$. A 10 - and 100 -fold dilution of E. huxleyi resulted in a 51 and $172 \%$ increase in cell-normalized net extracellular $\mathrm{O}_{2}^{-}$production rates, respectively.
Although average rates increased at both dilution levels, only the 100-fold dilution resulted with significantly more extracellular $\mathrm{O}_{2}^{-}$per cell than the undiluted control ( $t$-test; $p<0.05$ ) (Figure 3). The $0.22 \mu \mathrm{m}$ filtered, autoclaved seawater diluent was also measured for $\mathrm{O}_{2}^{-}$to ensure the $\mathrm{O}_{2}^{-}$measured in the diluted samples was not due to the seawater diluent. At maximum, $\mathrm{O}_{2}^{-}$produced in the seawater diluent could only account for $3.0-4.6 \%$ of the total steady-state $\mathrm{O}_{2}^{-}$concentrations measured in experiments with E. huxleyi, confirming that the contribution from the diluent was negligible.

\section{SOD Addition Experiments}

To assess how extracellular $\mathrm{O}_{2}^{-}$influences growth and physiology, E. huxleyi cultures were grown with a range of SOD concentrations and monitored until the end of exponential phase. Since SOD is a large enzyme ( $>31 \mathrm{kDa})$ (Cass, 1985), it cannot passively cross cell membranes and therefore selectively targets $\mathrm{O}_{2}^{-}$within the extracellular milieu. Overall, the addition of SOD stimulated growth (Figure 4; Supplementary Figure S2; Supplementary Table S2). For example, in vivo fluorescence was significantly different in cultures with various SOD concentrations (mixed factor repeated measures ANOVA; $p<0.001$ ) and became more significant over time (mixed factor repeated measures ANOVA; $p<0.0001$ ) (Figure 4A; Supplementary Table S2). In addition, specific growth rates were between 15 and $22 \%$ higher $(t$-test; $p<0.05)$ in the presence of SOD (Figure 4B; Supplementary Table S2). Cell abundances from cultures grown with $100 \mathrm{U} \mathrm{ml}^{-1}$ SOD were significantly higher $(t$-test; $p<0.05)$ than cell abundances from cultures grown without SOD beginning on day 7 (Figure 4C; Supplementary Table S2), when cell concentrations in the highest SOD addition were $41 \%$ higher than the unamended treatment.

To confirm whether these results were specifically due to SOD, a control experiment was performed in which SOD was removed via diafiltration and only the low molecular weight fraction $(<10 \mathrm{kDa})$ of the SOD suspension was added to cultures. In vivo fluorescence was significantly different between treatments (mixed factor repeated measures ANOVA; $p<0.05$ ) with significance increasing over time (mixed factor repeated measures ANOVA; $p<0.0001$ ) (Supplementary Figure S2A; Supplementary Table S2). Cultures grown with SOD grew significantly faster $(t$-test; $p<0.05)$ than those grown with dialyzed SOD (Figure 2B; Supplementary Table S2). By the end of the control experiment (day 12), cell abundances from cultures grown with dialyzed SOD were significantly lower $(t$-test; $p<0.05)$ than those grown with SOD by about $32 \%$ (Supplementary Figure S2C; Supplementary Table S2). Thus, the effect of SOD addition on growth rates and growth yields could not be accounted for by the dialyzed SOD control (Supplementary Figure S2; Supplementary Table S2).

In addition to growth yields and growth rates, the cellular biovolume of E. huxleyi was monitored in SOD addition experiments. Biovolume was calculated using three different methods, but regardless of the calculation method used, cellular biovolume was larger in cultures grown with SOD ( $t$-test; $p<0.0001$ ) (Figure 5A; Supplementary Figure S3A; 


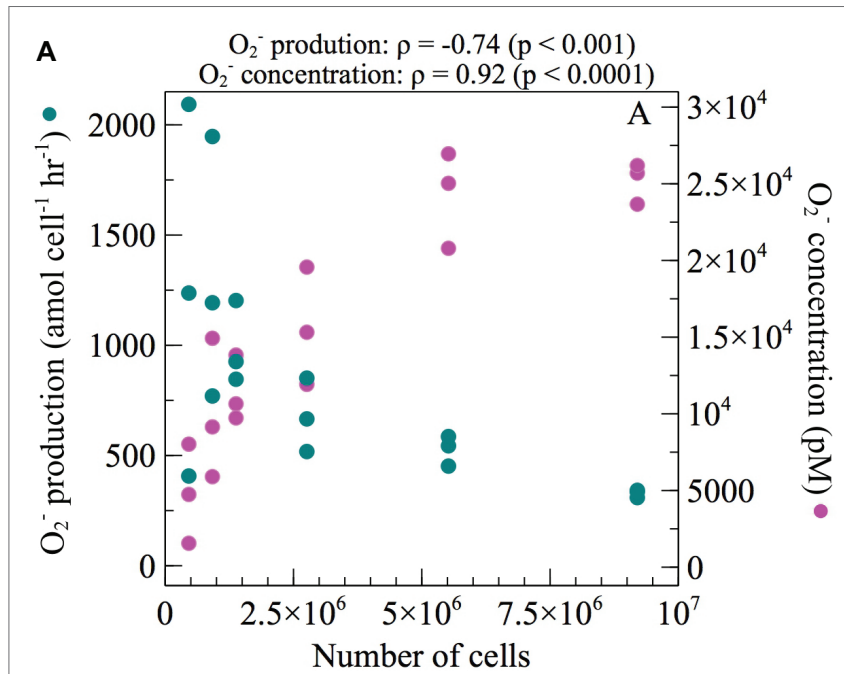

B $\quad \mathrm{O}_{2}^{-}$production: $\rho=-0.20(\mathrm{p}=0.45)$

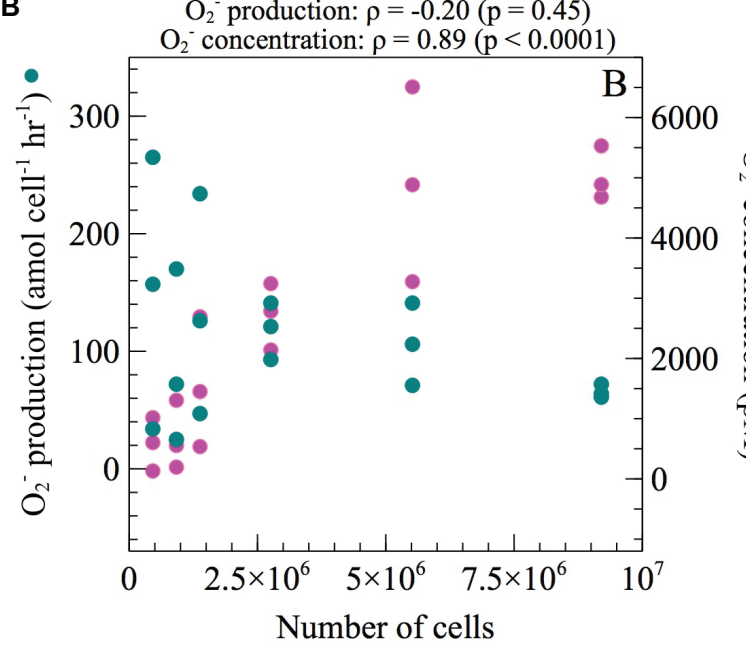

FIGURE 2 | Net per-cell $\mathrm{O}_{2}^{-}$production rates and total steady-state $\mathrm{O}_{2}^{-}$ concentrations were measured across a range of increasing cell numbers during (A) exponential and (B) stationary growth phases of $E$. huxleyi.

Regression analysis was performed using Spearman's rank-order correlation. Correlation coefficients $(\rho)$ and their level of significance $(p)$ are provided.

Supplementary Table S2). Adding SOD increased biovolume between 6.3 and $22.1 \%$, depending on the SOD concentration and calculation method used. In the control experiment with dialyzed SOD, biovolume of cells grown with SOD was significantly larger ( $t$-test; $p<0.0001$ ) than those grown with dialyzed SOD by at least 19\% (Supplementary Figure S3A; Supplementary Table S2) confirming the response was due to the presence of SOD.

In addition to stimulating growth, SOD improved photophysiological health, as evidenced by increased $F_{v} / F_{m}$ values, which indicated more efficient light assimilation by PSII in the presence of SOD. By day 10, adding SOD at each concentration increased $F_{v} / F_{m}$ between 11 and $18 \%$ compared to the $0 \mathrm{U} \mathrm{ml}^{-1} \mathrm{SOD}$ control ( $t$-test; $p<0.05$ ) (Figure 5B; Supplementary Table S2). A similar trend was

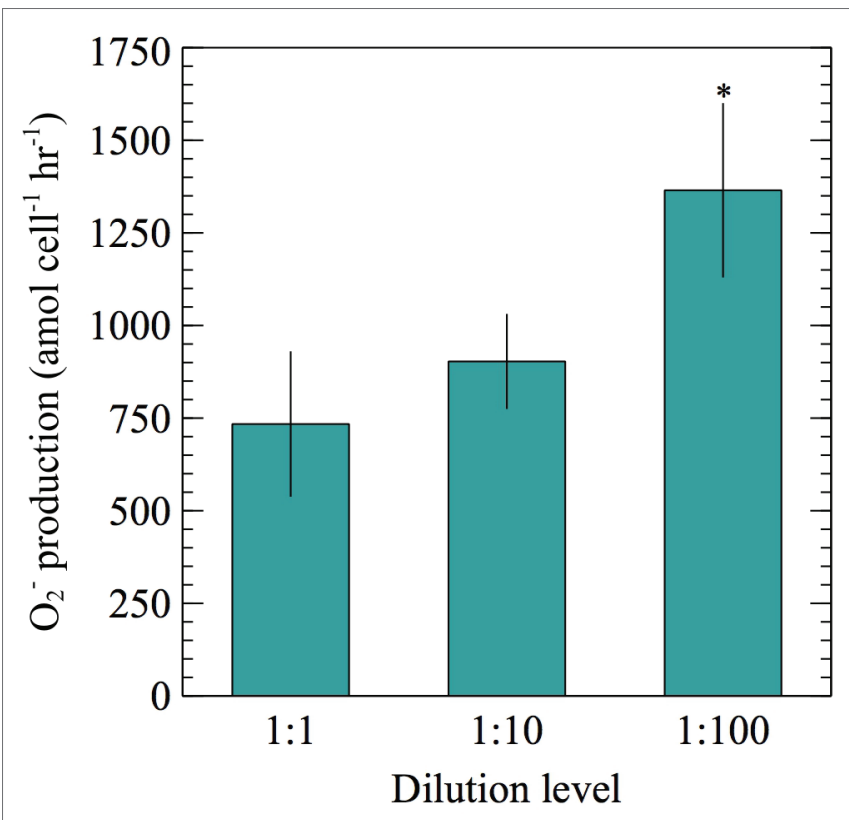

FIGURE 3 | Net per-cell $\mathrm{O}_{2}^{-}$production rates were measured from $\sim 10^{6}$ E. huxleyi cells during exponential growth phase post no dilution (1:1), 10-fold dilution (1:10), or 100-fold dilution (1:100) with $0.22 \mu \mathrm{m}$ filtered, autoclaved seawater for 0-6.5 h. Significant differences (two sample Student's t-test) relative to the undiluted control (1:1) are indicated by asterisks, where $p<0.05$ is represented by * symbol. Error bars depict one standard error of the mean of replicates ( $n=8$ for $1: 100$ and 9 for $1: 1$ and $1: 10$ dilutions).

seen in the control experiment with dialyzed SOD, where $F_{v} / F_{m}$ values from cultures grown with SOD were significantly higher than those from cultures grown with dialyzed SOD starting on day 7 ( $t$-test; $p<0.05$ ) (Supplementary Figure S3B; Supplementary Table S2). Therefore, improvements in photophysiological health are attributed to the effects of SOD.

\section{Extracellular $\mathrm{O}_{2}^{-}$Production in the Presence and Absence of Light}

To investigate whether extracellular $\mathrm{O}_{2}^{-}$production by E. huxleyi is dependent on light, extracellular $\mathrm{O}_{2}^{-}$production was measured in ambient light and dark conditions. A representative FeLume time series measurement of $\mathrm{O}_{2}^{-}$concentration showed that extracellular $\mathrm{O}_{2}^{-}$production by E. huxleyi under ambient light reached and stabilized at 2,395 $\pm 27 \mathrm{pM}$ (Figure 6). Upon removal of light, there was an immediate decline in production, which stabilized at 1,085 $\pm 29 \mathrm{pM}$ after $\sim 160 \mathrm{~s}$ in dark conditions. This result could not be accounted for by abiotic factors, as the removal of light had insignificant effects on $\mathrm{O}_{2}^{-}$ production in the absence of E. huxleyi cells. The drawdown of signal below the abiotic $\mathrm{O}_{2}^{-}$baseline by SOD confirmed that the biogenic signal was indeed due to $\mathrm{O}_{2}^{-}$production (Figure 6). All biological replicates produced less $\mathrm{O}_{2}^{-}$in dark compared to ambient light conditions ( $t$-test; $p<0.0001$ ), indicating a connection with photophysiological processes (Figure 7). Dark conditions inhibited $\mathrm{O}_{2}^{-}$production by an average of $70 \%$. 
A

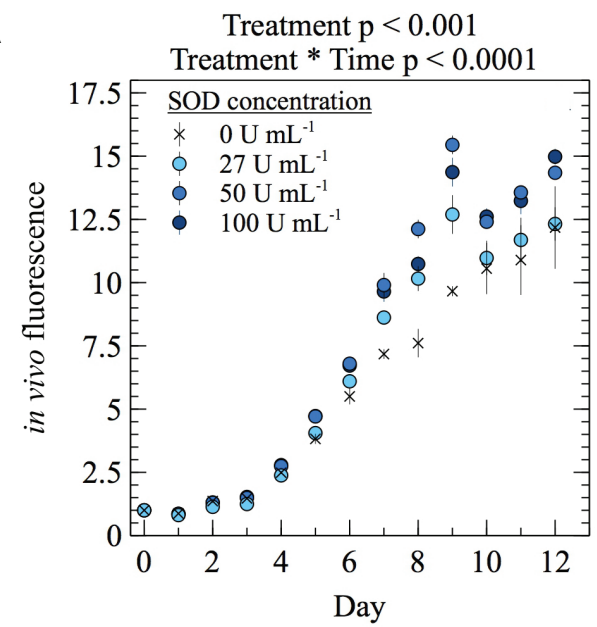

B

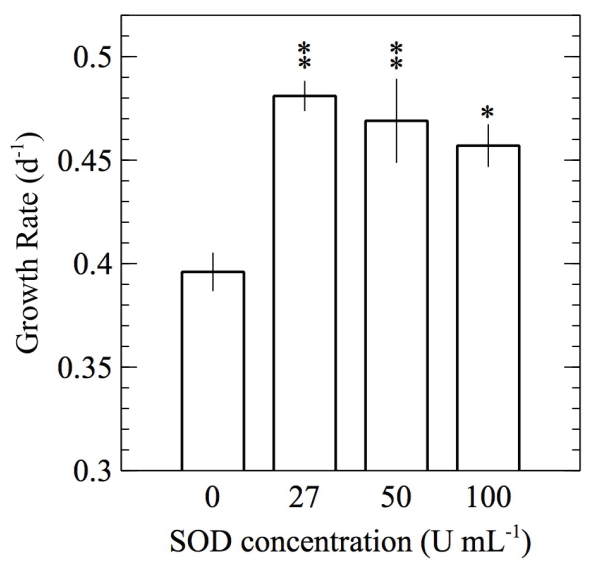

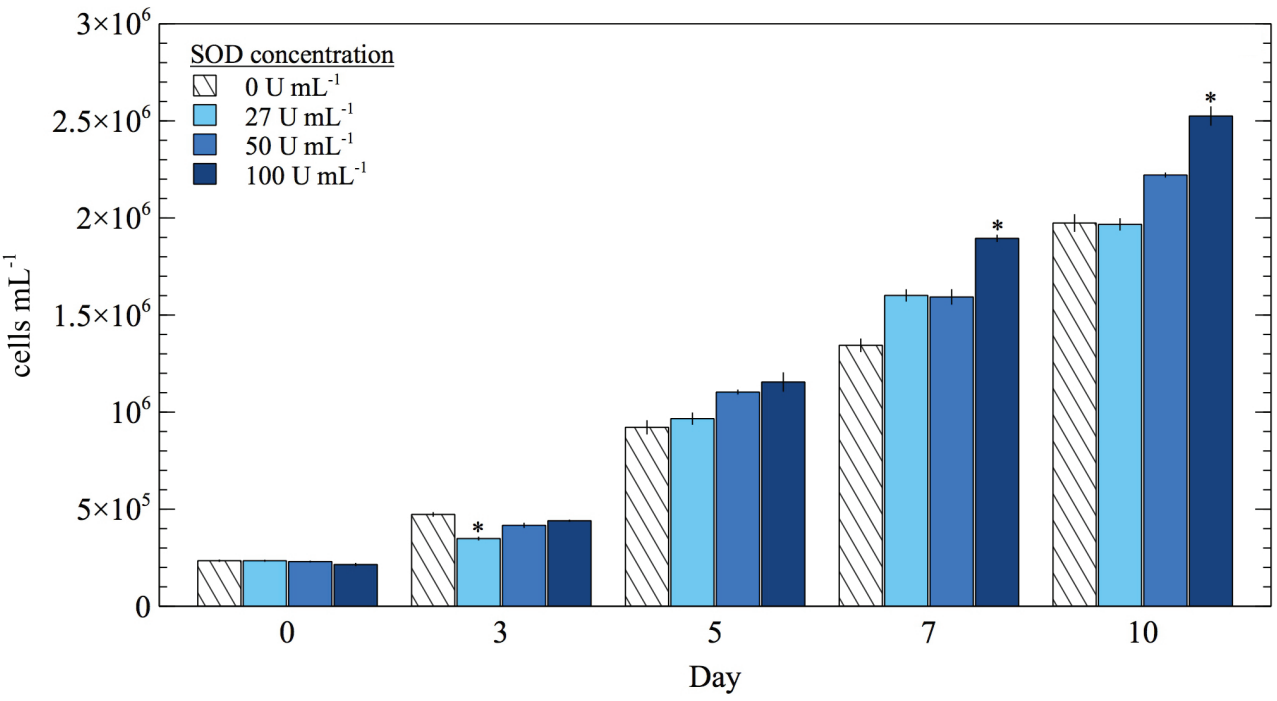

FIGURE 4 | The effect of daily SOD additions on (A) average in vivo fluorescence, (B) specific growth rate during exponential growth phase, and (C) cell abundance of $E$. huxleyi. Significant differences in in vivo fluorescence between SOD additions were found using a mixed factor repeated measures ANOVA. Significant differences (two sample Student's $t$-test) in specific growth rate and cell abundances relative to the control $\left(0 \mathrm{U} \mathrm{ml}^{-1} \mathrm{SOD}\right)$ are indicated by asterisks, where $p<0.05$ and $<0.01$ are represented by * and ** symbols, respectively. Error bars depict one standard error of the mean of biological replicates $(n=3$ ).

\section{DISCUSSION}

Here, we investigated the cellular regulation and potential physiological roles of extracellular $\mathrm{O}_{2}^{-}$production in a noncalcifying strain (CCMP 374) of the cosmopolitan marine coccolithophore E. huxleyi to approach a broader understanding of the potential ecological and environmental impacts of phytoplankton-derived extracellular $\mathrm{O}_{2}^{-}$. The ability to produce extracellular $\mathrm{O}_{2}^{-}$is widespread among phytoplankton, yet production rates can vary substantially within and between species (Diaz and Plummer, 2018). For example, compared to Chattonella spp., the most prolific microbial ROS producers, maximal extracellular $\mathrm{O}_{2}^{-}$ production rates by $E$. huxleyi were about 100-10,000 times lower. Indeed, E. huxleyi produced $\mathrm{O}_{2}^{-}$at a rate more similar to nonharmful algae such as Symbiodinium spp. and Thalassiosira spp. (Diaz and Plummer, 2018).
The extracellular $\mathrm{O}_{2}^{-}$concentrations and production rates by E. huxleyi were not due to the release of intracellular $\mathrm{O}_{2}^{-}$. First, the release of intracellular $\mathrm{O}_{2}^{-}$through cell lysis would have been detected as a rapidly decaying pulse of $\mathrm{O}_{2}^{-}$, but this can be ruled out because $\mathrm{O}_{2}^{-}$signals were stable for at least 1-2 min (see section "Materials and Methods"), a significant timeframe compared to the typical half-life of $\mathrm{O}_{2}^{-}$in our analysis ( 2 min) (Diaz et al., 2013). Second, the physiochemical nature of the $\mathrm{O}_{2}^{-}$anion prevents it from passively crossing intact cell membranes (Bielski et al., 1985; Lesser, 2006; Brown and Griendling, 2009). Therefore, the production rates measured in this study reflect active production of $\mathrm{O}_{2}^{-}$on or near the surface of E. huxleyi. The reported rates of extracellular $\mathrm{O}_{2}^{-}$production reflect the balance of gross production and decay at the cell surface, thus giving a net production rate. Therefore, any change in the net production rate of extracellular $\mathrm{O}_{2}^{-}$could result from a change in gross production, decay, or both. Several abiotic 


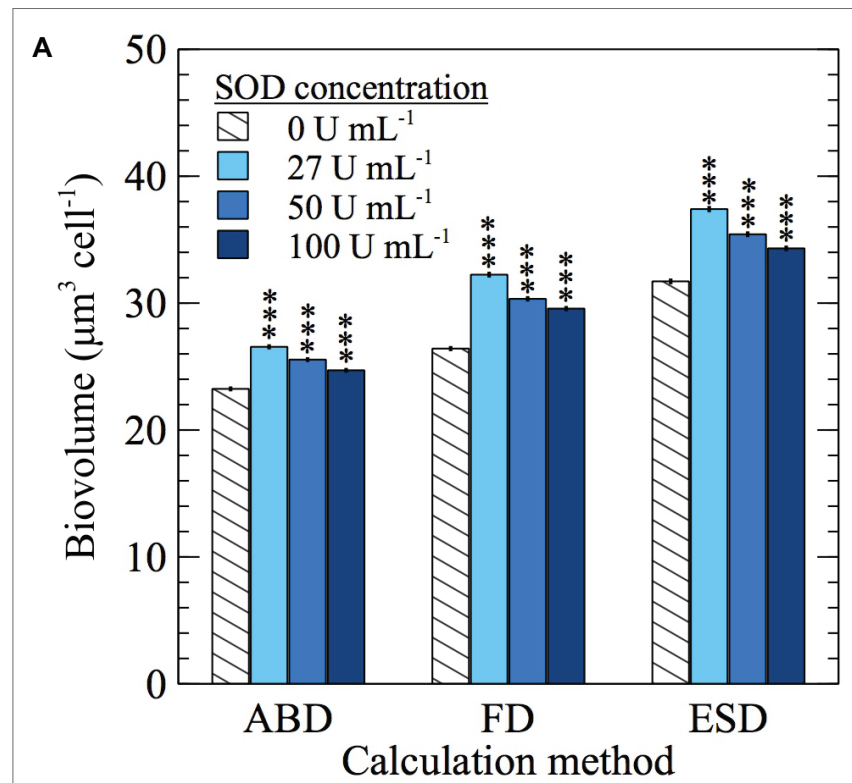

B

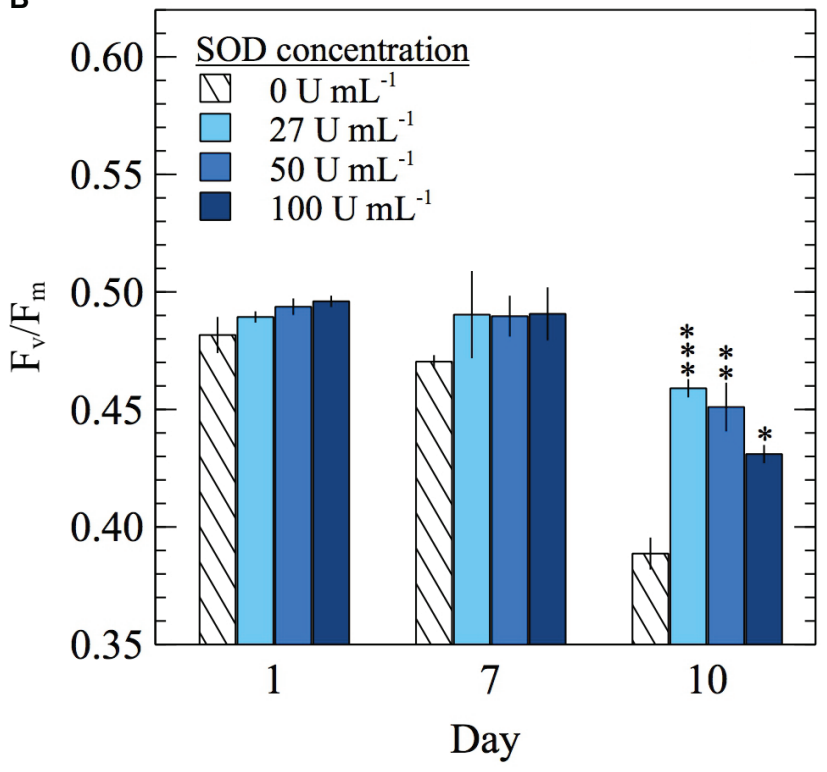

FIGURE 5 | The effect of daily SOD additions on E. huxleyi (A) cellular biovolume ( $n=19,041,17,344,24,902$, and 33,006 individual cells for 0,27 , 50 , and $100 \mathrm{U} \mathrm{ml}^{-1} \mathrm{SOD}$, respectively) sampled on day 10 and calculated using three different measurements of cell diameter [area based diameter (ABD), filled or full diameter (FD), and equivalent spherical diameter (ESD)] and (B) $F_{v} / F_{m}$ values ( $n=3$ biological replicates). Significant differences (two sample Student's $t$-test) relative to the control $\left(0 \mathrm{U} \mathrm{ml}^{-1} \mathrm{SOD}\right)$ are indicated by asterisks, where $p<0.05,<0.01$, and $<0.0001$ are represented by *, ${ }^{*}$, and *** asterisk symbols, respectively. Error bars represent one standard error of the mean.

and biotic factors have the potential to degrade extracellular $\mathrm{O}_{2}^{-}$ at or near the cell surface, such as interactions with trace metals including soluble and mineral-bound iron (Fujii et al., 2006; Heller and Croot, 2010a) and expression of cell surface SODs (Aguirre et al., 2005; Oshikawa et al., 2010; Bauer, 2014).
ROS production is commonly associated with stress; however, E. huxleyi produced extracellular $\mathrm{O}_{2}^{-}$without any added stressors. In fact, cell-normalized $\mathrm{O}_{2}^{-}$production by E. huxleyi was the highest in early exponential phase under presumably the least taxing culture conditions when nutrient concentrations were the highest (Figure 1) and when photosynthetic efficiency was at a maximum (Supplementary Figure S1). These results reflect the rates of extracellular $\mathrm{O}_{2}^{-}$production by cells that were removed from the prevailing culture conditions and analyzed ex situ. The ex situ analytical conditions such as $\mathrm{pH}$ (7.6) were identical across culture samples of all ages, yet differed from in situ levels (Supplementary Figure S4). These results therefore show that as cultures age, there is a shift toward lower $\mathrm{O}_{2}^{-}$production when cells are analyzed under the same conditions. The potential effect of $\mathrm{pH}$ on extracellular $\mathrm{O}_{2}^{-}$production by E. huxleyi is unknown, but an increase in $\mathrm{pH}$ stimulates extracellular ROS production by C. marina (Liu et al., 2007), which is opposite to the trend reported here (Figure 1; Supplementary Figure S4). The observed decline in extracellular $\mathrm{O}_{2}^{-}$production with culture age therefore suggests that extracellular $\mathrm{O}_{2}^{-}$production is physiologically driven and unlikely related to a stress response, as levels of stress would presumably increase with time in batch culture due to the depletion of resources. These findings do not rule out the potential for E. huxleyi to upregulate extracellular $\mathrm{O}_{2}^{-}$under stressful conditions, as seen with extracellular $\mathrm{H}_{2} \mathrm{O}_{2}$ (Evans et al., 2006) and intracellular ROS (Evans et al., 2006; Vardi et al., 2012) during viral infection, but do demonstrate a physiological investment in the production of extracellular $\mathrm{O}_{2}^{-}$under ideal growth conditions, which suggests some role in basal metabolism. In order to clarify if and how E. huxleyi regulates extracellular $\mathrm{O}_{2}^{-}$in response to biogeochemical variability and stress, future work should consider the influence of factors such as viral infection and $\mathrm{pH}$.

In addition to having growth phase dependence (Figure 1) similar to other phytoplankton (Oda et al., 1995; Kim et al., 1999; Portune et al., 2010), cell-normalized net extracellular $\mathrm{O}_{2}^{-}$production rates by $E$. huxleyi were also inversely dependent on cell density over a range of timescales during exponential growth phase. For example, this trend occurred when cell density increased on time scales of seconds to minutes (Figure 2A) and when cells were preconditioned to lower cell densities on timescales of minutes to hours (Figure 3 ). This tight regulation may suggest a dynamic cell density-dependent signaling role for $\mathrm{O}_{2}^{-}$production in E. huxleyi. For instance, extracellular $\mathrm{O}_{2}^{-}$deriving from one cell may act as a signal between other cells or within the same cell to provide information on surrounding population density (Diaz and Plummer, 2018). Similar cell density dependent trends in extracellular $\mathrm{O}_{2}^{-}$ production have been demonstrated in other phytoplankton (Marshall et al., 2005a; Hansel et al., 2016; Diaz et al., 2018), including C. marina (Marshall et al., 2005b).

Although evidence has been accumulating that extracellular $\mathrm{O}_{2}^{-}$ production is directly involved in growth promotion in a range of microbial cell types (Oda et al., 1995; Aguirre et al., 2005), our results show that the presence of extracellular $\mathrm{O}_{2}^{-}$does not directly stimulate growth of E. huxleyi. The potential role of extracellular $\mathrm{O}_{2}^{-}$in E. huxleyi growth was addressed through selective removal of extracellular $\mathrm{O}_{2}^{-}$from the local environment 


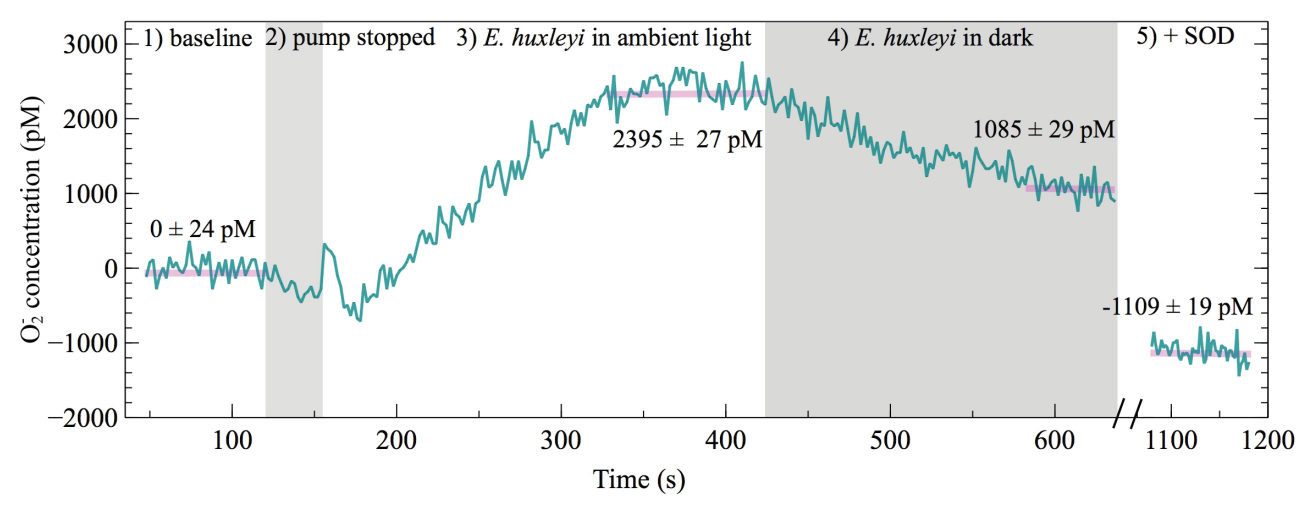

FIGURE 6 | FeLume time-series of $\mathrm{O}_{2}^{-}$measurements under different light conditions on day 2 of E. huxleyi growth (biological replicate B) split into five regions: (1) phosphate buffer solution and MCLA reagent baseline (which is subtracted from the biogenic $\mathrm{O}_{2}^{-}$concentration in regions 3 and 4), (2) shaded region showing loading of E. huxleyi cells while the pump was stopped, (3) E. huxleyi in ambient light, (4) the second shaded region showing E. huxleyi in the dark, and (5) drawdown of the $\mathrm{O}_{2}^{-}$signal below the baseline after addition of SOD (negative $\mathrm{O}_{2}^{-}$concentrations account for SOD driven degradation of $\mathrm{O}_{2}^{-}$originating from auto-oxidation of the MCLA reagent). The average \pm SE of stable steady-state $\mathrm{O}_{2}^{-}$concentration measurements are indicated by horizontal pink lines.

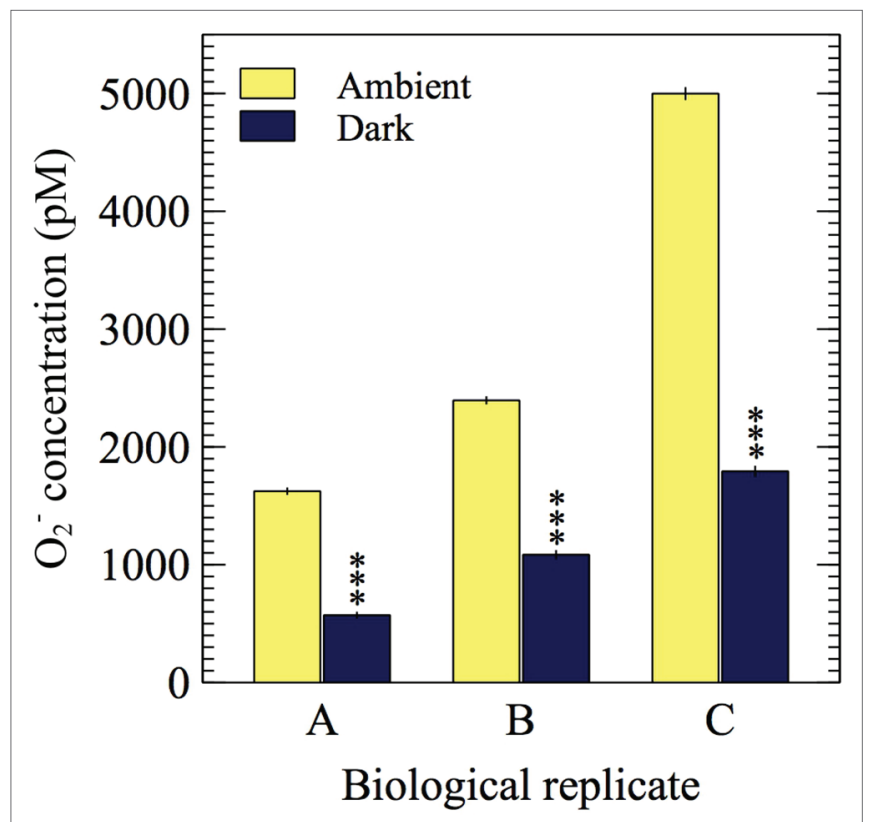

FIGURE 7 | $\mathrm{O}_{2}^{-}$measurements from three biological replicates of $E$. huxleyi in the presence of ambient light $\left(\sim 5 \mu \mathrm{mol}\right.$ photons $\left.\mathrm{m}^{-2} \mathrm{~s}^{-1}\right)$ and in the dark $\left(0 \mu \mathrm{mol}\right.$ photons $\left.\mathrm{m}^{-2} \mathrm{~s}^{-1}\right)$. Asterisks show significant difference $(p<0.0001)$ between the average dark and average ambient light steady-state $\mathrm{O}_{2}^{-}$ concentration for each biological replicate. Error bars represent one standard error of the mean ( $n \geq 31$ chemiluminescent counts).

of cells using SOD. Scavenging $\mathrm{O}_{2}^{-}$promoted growth (Figure 4), increased cell biovolume (Figure 5A), and improved photosynthetic efficiency (Figure 5B). Conversely, removal of extracellular $\mathrm{O}_{2}^{-}$ from cultures of Chattonella spp. attenuates growth (Tanaka et al., 1992; Oda et al., 1995). Specifically, in one prior study, C. marina growth was significantly hampered under similar SOD concentrations used in the present study, and the morphological state of cells was altered (Oda et al., 1995). Recently,
Hansel et al. (2019) revealed that the growth of common marine bacteria from the Roseobacter clade was inhibited by SOD in a dose-dependent manner (Hansel et al., 2019). Similarly, the removal of extracellular ROS from fungi and the amoebozoan Dictyostelium discoideum is also detrimental to development (Aguirre et al., 2005). Taken together, extracellular $\mathrm{O}_{2}^{-}$does not seem to directly stimulate growth in E. huxleyi. Rather, these results may highlight a different role for extracellular $\mathrm{O}_{2}^{-}$in E. huxleyi that contrasts with the proposed growth-promoting role of extracellular $\mathrm{O}_{2}^{-}$ in C. marina (Oda et al., 1995), bacteria (Hansel et al., 2019), fungi, and protists (Aguirre et al., 2005). However, the addition of SOD not only removes $\mathrm{O}_{2}^{-}$but produces $\mathrm{H}_{2} \mathrm{O}_{2}$, which may also have impacts on E. huxleyi physiology. For example, high concentrations of $\mathrm{H}_{2} \mathrm{O}_{2}$ are harmful to phytoplankton (Dupouy et al., 1985; Morris et al., 2011), but normal growth of C. marina is dependent on low levels of extracellular $\mathrm{H}_{2} \mathrm{O}_{2}$ (Oda et al., 1995). In fact, in a variety of cell types, the dismutation of Nox-derived $\mathrm{O}_{2}^{-}$by cell surface SOD generates extracellular $\mathrm{H}_{2} \mathrm{O}_{2}$, which can diffuse into the cell, to elicit gene expression (Shapiguzov et al., 2012), morphogenesis (Rossi et al., 2017), and proliferation (Oshikawa et al., 2010; Bauer, 2014). It remains possible, yet speculative, that the addition of SOD in our experiments accelerated the dismutation of $\mathrm{O}_{2}^{-}$to $\mathrm{H}_{2} \mathrm{O}_{2}$, which then may have acted as a growth promoter for E. huxleyi. Thus, the role of extracellular $\mathrm{O}_{2}^{-}$in E. huxleyi may be contingent on its ability to give rise to $\mathrm{H}_{2} \mathrm{O}_{2}$, which should be interrogated in future work.

The fact that there are clear trends in extracellular $\mathrm{O}_{2}^{-}$ production as a function of growth phase and cell density, but that E. huxleyi growth was not stunted with removal of extracellular $\mathrm{O}_{2}^{-}$, leaves the possibility open that extracellular $\mathrm{O}_{2}^{-}$could be connected to other aspects of E. huxleyi physiology and health. To examine whether extracellular $\mathrm{O}_{2}^{-}$production may be involved in photosynthetic physiology, we interrogated $\mathrm{O}_{2}^{-}$production as a function of light and found that $\mathrm{O}_{2}^{-}$production was attenuated within seconds upon transition from light to dark conditions (Figure 6). 
This finding adds to a growing body of evidence linking modulation of extracellular $\mathrm{O}_{2}^{-}$production by phytoplankton to light availability and therefore photophysiology. For instance, extracellular $\mathrm{O}_{2}^{-}$production is light dependent in many phytoplankton including Thalassiosira spp. (Milne et al., 2009; Schneider et al., 2016), Trichodesmium (Hansel et al., 2016), Symbiodinium (modulated on the same time scales shown here) (Saragosti et al., 2010), and Chattonella spp. (Kim et al., 1999; Marshall et al., 2002; Dorantes-Aranda et al., 2013). Thus, $\mathrm{O}_{2}^{-}$production may somehow be involved with light dependent processes (e.g., photosynthesis, photoacclimation physiology), and this functionality may be conserved across phytoplankton taxa. Interestingly, in a previous study, when C. marina was treated with DCMU [3-(3,4-dichlorophenyl)1,1-dimethylurea], an electron transfer inhibitor between photosystem II and I, extracellular $\mathrm{O}_{2}^{-}$production was quenched to levels observed under dark conditions (Marshall et al., 2002), further illustrating a mechanistic link between extracellular $\mathrm{O}_{2}^{-}$ production and photophysiology.

Overall, this study reveals that the stress-independent production of extracellular $\mathrm{O}_{2}^{-}$by E. huxleyi is dynamically regulated, and potentially part of a basal process involved with photophysiology. Extracellular $\mathrm{O}_{2}^{-}$production by $E$. huxleyi is conceivably part of healthy cellular functioning for several reasons. First, the fact that cells diverted energy toward making $\mathrm{O}_{2}^{-}$in the absence of a stressor suggests its production can be unassociated with stress and probably related to basal functioning. Indeed, E. huxleyi produced maximum amounts of extracellular $\mathrm{O}_{2}^{-}$per cell under ideal growth conditions while cells were most metabolically active (Figure 1) and when efficiency of photosynthetic processes was the highest (Supplementary Figure S1). Further, the steady-state concentrations of $\mathrm{O}_{2}^{-}$generated by $E$. huxleyi cells are not consistent with concentrations that would be damaging $\left(>10^{-6} \mathrm{M}\right)$ but are consistent with concentrations of biological signaling molecules $\left(\sim 10^{-12} \mathrm{M}\right)$ (Saran, 2003). Additionally, E. huxleyi cells tightly controlled the production of extracellular $\mathrm{O}_{2}^{-}$as a function of light, cell density, and growth phase, and on timescales as short as seconds, consistent with other phytoplankton (Oda et al., 1995; Kim et al., 1999; Marshall et al., 2002, 2005a,b; Milne et al., 2009; Portune et al., 2010; Saragosti et al., 2010; Dorantes-Aranda et al., 2013; Hansel et al., 2016; Schneider et al., 2016; Diaz et al., 2018), suggesting a potential dynamic role in signaling and photophysiology. Indeed, stress-independent extracellular $\mathrm{O}_{2}^{-}$production by E. huxleyi is in agreement with several other microorganisms such as phytoplankton and bacteria where its production is prolific under ideal growth conditions (Oda et al., 1995; Kustka et al., 2005; Rose et al., 2005; Marshall et al., 2005a,b; Godrant et al., 2009; Portune et al., 2010; Diaz et al., 2013; Hansel et al., 2016; Schneider et al., 2016). The fact that E. huxleyi still produces extracellular $\mathrm{O}_{2}^{-}$in the absence of light suggests there could be additional and/or alternative purposes for this production beyond photophysiology. Indeed, extracellular $\mathrm{O}_{2}^{-}$ production can be produced through a variety of subcellular mechanisms and could be produced for a combination of ecophysiological functions (Diaz and Plummer, 2018).
Contrasting with other diverse microorganisms (Tanaka et al., 1992; Oda et al., 1995; Saran, 2003; Aguirre et al., 2005; Hansel et al., 2019), the presence of extracellular $\mathrm{O}_{2}^{-}$does not promote growth in E. huxleyi. This finding underscores a potentially unprecedented role for the presence and/or production of extracellular $\mathrm{O}_{2}^{-}$, which should be investigated among other phytoplankton. Finally, non-calcifying E. huxleyi cells coexist with calcareous varieties in nature but typically are not dominant (Frada et al., 2012). Several ecological and physiological processes are variable within (Strom et al., 2003; Strom and Bright, 2009; Sunda and Hardison, 2010; Harvey et al., 2015; Poulson-Ellestad et al., 2016) and between (Paasche, 2002; Suggett et al., 2007; Harvey et al., 2015; Poulson-Ellestad et al., 2016) calcifying and noncalcifying strains. Whether the rates, regulation, and roles of extracellular $\mathrm{O}_{2}^{-}$production are different in calcifying versus noncalcifying strains of $E$. huxleyi has yet to be determined but should be considered in future work.

\section{DATA AVAILABILITY}

Any materials and data will be made available to members of the scientific community upon request.

\section{AUTHOR CONTRIBUTIONS}

SP and JD conceived the study. SP conducted the experiments and data analysis, with contributions from AT. All authors contributed to interpretation of results and preparing the manuscript.

\section{FUNDING}

This research was supported by a Junior Faculty Seed Grant from the University of Georgia Research Foundation (JD), a National Science Foundation (NSF) Graduate Research Fellowship (SP), and NSF grant OCE-1355720 (CH). The FlowCam ${ }^{\circledR}$ and FIRe were purchased through a NSF Equipment Improvement Grant (1624593).

\section{ACKNOWLEDGMENTS}

The authors wish to thank Dee King for her assistance with literature searches and reference indexing, Dr. Patricia Yager and Dr. Brian Hopkinson for use of their labs, and Rachel Steffen for assistance in the lab.

\section{SUPPLEMENTARY MATERIAL}

The Supplementary Material for this article can be found online at: https://www.frontiersin.org/articles/10.3389/fmicb.2019.01546/ full\#supplementary-material 


\section{REFERENCES}

Aguirre, J., and Lambeth, J. D. (2010). Nox enzymes from fungus to fly to fish and what they tell us about Nox function in mammals. Free Radic. Biol. Med. 49, 1342-1353. doi: 10.1016/j.freeradbiomed.2010.07.027

Aguirre, J., Rios-Momberg, M., Hewitt, D., and Hansberg, W. (2005). Reactive oxygen species and development in microbial eukaryotes. Trends Microbiol. 13, 111-118. doi: 10.1016/j.tim.2005.01.007

Anderson, A., Laohavisit, A., Blaby, I. K., Bombelli, P., Howe, C. J., Merchant, S. S., et al. (2015). Exploiting algal NADPH oxidase for biophotovoltaic energy. Plant Biotechnol. J. 14, 22-28. doi: 10.1111/pbi.12332

Bauer, G. (2014). Targeting extracellular ROS signaling of tumor cells. Anticancer Res. 34, 1467-1482. Retrieved from: http://ar.iiarjournals.org.

Bielski, B. H. J., Cabelli, D. E., Arudi, R. L., and Ross, A. B. (1985). Reactivity of $\mathrm{H}_{2} \mathrm{O} / \mathrm{O}_{2}^{-}$radicals in aqueous-solution. J. Phys. Chem. Ref. Data 14, 1041-1100. doi: 10.1063/1.555739

Brown, D. I., and Griendling, K. K. (2009). Nox proteins in signal transduction. Free Radic. Biol. Med. 47, 1239-1253. doi: 10.1016/j.freeradbiomed.2009.07.023

Brown, C. W., and Yoder, J. A. (1994). Coccolithophorid blooms in the global ocean. J. Geophys. Res. Oceans 99, 7467-7482. doi: 10.1029/93JC02156

Cass, A. E. G. (1985). "Superoxide dismutases" in Metalloproteins. ed. P. M. Harrison (London: Palgrave Macmillan UK), 121-156.

Diaz, J. M., Hansel, C. M., Apprill, A., Brighi, C., Zhang, T., Weber, L., et al. (2016). Species-specific control of external superoxide levels by the coral holobiont during a natural bleaching event. Nat. Commun. 7:13801. doi: $10.1038 /$ ncomms 13801

Diaz, J. M., Hansel, C. M., Voelker, B. M., Mendes, C. M., Andeer, P. F., and Zhang, T. (2013). Widespread production of extracellular superoxide by heterotrophic bacteria. Science 340, 1223-1226. doi: 10.1126/ science. 1237331

Diaz, J. M., and Plummer, S. (2018). Production of extracellular reactive oxygen species by phytoplankton: past and future directions. J. Plankton Res. 40, 655-666. doi: 10.1093/plankt/fby039

Diaz, J. M., Plummer, S., Tomas, C., and Alves-De-Souza, C. (2018). Production of extracellular superoxide and hydrogen peroxide by five marine species of harmful bloom-forming algae. J. Plankton Res. 40, 667-677. doi: 10.1093/ plankt/fby043

Dorantes-Aranda, J. J., Nichols, P. D., Waite, T. D., and Hallegraeff, G. M. (2013). Strain variability in fatty acid composition of Chattonella marina (Raphidophyceae) and its relation to differing ichthyotoxicity toward rainbow trout gill cells. J. Phycol. 49, 427-438. doi: 10.1111/jpy.12053

Dorantes-Aranda, J. J., Seger, A., Mardones, J. I., Nichols, P. D., and Hallegraeff, G. M. (2015). Progress in understanding algal bloom-mediated fish kills: the role of superoxide radicals, phycotoxins and fatty acids. PLoS One 10:e0133549. doi: 10.1371/journal.pone.0133549

Dupouy, D., Conter, A., Croute, F., Murat, M., and Planel, H. (1985). Sensitivity of Synechococcus lividus to hydrogen peroxide. Environ. Exp. Bot. 25, 339-347. doi: 10.1016/0098-8472(85)90031-0

Evans, C., Malin, G., Mills, G. P., and Wilson, W. H. (2006). Viral infection of Emiliania huxleyi (prymnesiophyceae) leads to elevated production of reactive oxygen species. J. Phycol. 42, 1040-1047. doi: 10.1111/j.15298817.2006.00256.x

Flores, H. S., Wikfors, G., and Dam, H. (2012). Reactive oxygen species are linked to the toxicity of the dinoflagellate Alexandrium spp. to protists. Aquat. Microb. Ecol. 66, 199-209. doi: 10.3354/ame01570

Frada, M. J., Bidle, K. D., Probert, I., and De Vargas, C. (2012). In situ survey of life cycle phases of the coccolithophore Emiliania huxleyi (Haptophyta). Environ. Microbiol. 14, 1558-1569. doi: 10.1111/j.1462-2920.2012.02745.x

Fujii, M., Rose, A. L., Waite, T. D., and Omura, T. (2006). Superoxide-mediated dissolution of amorphous ferric oxyhydroxide in seawater. Environ. Sci. Technol. 40, 880-887. doi: 10.1021/es051622t

Fujimori, K., Nakajima, H., Akutsu, K., Mitani, M., Sawada, H., and Nakayama, M. (1993). Chemiluminescence of Cypridina luciferin analogues. Part 1. Effect of $\mathrm{pH}$ on rates of spontaneous autoxidation of CLA in aqueous buffer solutions. J. Chem. Soc. Perkin Trans. 2, 2405-2409.

Garg, S., Rose, A. L., Godrant, A., and Waite, T. D. (2007). Iron uptake by the ichthyotoxic Chattonella marina (Raphidophyceae): impact of superoxide generation1. J. Phycol. 43, 978-991. doi: 10.1111/j.1529-8817.2007.00394.x
Godrant, A., Rose, A. L., Sarthou, G., and Waite, T. D. (2009). New method for the determination of extracellular production of superoxide by marine phytoplankton using the chemiluminescence probes MCLA and red-CLA. Limnol. Oceanogr. Methods 7, 682-692. doi: 10.4319/lom.2009.7.682

Guillard, R. R. L., and Ryther, J. H. (1962). Studies of marine planktonic diatoms: i. Cyclotella nana hustedt, and detonula confervacea (cleve) gran. Can. J. Microbiol. 8, 229-239. doi: 10.1139/m62-029

Hansard, P. S., Vermilyea, A. W., and Voelker, B. M. (2010). Measurements of superoxide radical concentration and decay kinetics in the Gulf of Alaska. Deep-Sea Res. I Oceanogr. Res. Pap. 57, 1111-1119. doi: 10.1016/j.dsr.2010.05.007

Hansel, C. M., Buchwald, C., Diaz, J. M., Ossolinski, J. E., Dyhrman, S. T., Mooy, V., et al. (2016). Dynamics of extracellular superoxide production by Trichodesmium colonies from the Sargasso Sea. Limnol. Oceanogr. 61, 1188-1200. doi: 10.1002/lno.10266

Hansel, C. M., Diaz, J. M., and Plummer, S. (2019). Tight regulation of extracellular superoxide points to its vital role in the physiology of the globally relevant Roseobacter clade. MBio. 10, e02668-e02618. doi: 10.1128/ mBio.02668-18

Harvey, E. L., Bidle, K. D., and Johnson, M. D. (2015). Consequences of strain variability and calcification in Emiliania huxleyi on microzooplankton grazing. J. Plankton Res. 37, 1137-1148. doi: 10.1093/plankt/fbv081

Heller, M. I., and Croot, P. L. (2010a). Application of a superoxide $\left(\mathrm{O}_{2}^{-}\right)$ thermal source (SOTS-1) for the determination and calibration of $\mathrm{O}_{2}^{-}$ fluxes in seawater. Anal. Chim. Acta 667, 1-13. doi: 10.1016/j.aca.2010.03.054

Heller, M. I., and Croot, P. L. (2010b). Kinetics of superoxide reactions with dissolved organic matter in tropical Atlantic surface waters near Cape Verde (TENATSO). J. Geophys. Res. 115:C12038. doi: 10.1029/2009JC006021

Hervé, C., Tonon, T., Collén, J., Corre, E., and Boyen, C. (2006). NADPH oxidases in eukaryotes: red algae provide new hints! Curr. Genet. 49, 190-204. doi: 10.1007/s00294-005-0044-Z

Kim, C. S., Lee, S. G., Lee, C. K., Kim, H. G., and Jung, J. (1999). Reactive oxygen species as causative agents in the ichthyotoxicity of the red tide dinoflagellate Cochlodinium polykrikoides. J. Plankton Res. 21, 2105-2115. doi: $10.1093 /$ plankt/21.11.2105

Kim, D., Nakamura, A., Okamoto, T., Komatsu, N., Oda, T., Iida, T., et al. (2000). Mechanism of superoxide anion generation in the toxic red tide phytoplankton Chattonella marina: possible involvement of $\mathrm{NAD}(\mathrm{P}) \mathrm{H}$ oxidase. Biochim. Biophys. Acta 1524, 220-227. doi: 10.1016/s0304-4165(00)00161-6 Kim, D., Nakashima, T., Matsuyama, Y., Niwano, Y., Yamaguchi, K., and Oda, T. (2007). Presence of the distinct systems responsible for superoxide anion and hydrogen peroxide generation in red tide phytoplankton Chattonella marina and Chattonella ovata. J. Plankton Res. 29, 241-247. doi: 10.1093/ plankt/fbm011

Kim, D., and Oda, T. (2010). "Possible factors responsible for the fish-killing mechanisms of the red tide phytoplankton, Chattonella marina and Cochlodinium polykrikoides" in Coastal Environmental and Ecosystem Issues of the East China Sea, eds. A. Ishimatsu and H.-J. Lie (Tokyo, Japan: TERRAPUB and Nagasaki University), 245-268.

Kustka, A. B., Shaked, Y., Milligan, A. J., King, D. W., and Morel, F. M. M. (2005). Extracellular production of superoxide by marine diatoms: contrasting effects on iron redox chemistry and bioavailability. Limnol. Oceanogr. 50, 1172-1180. doi: 10.4319/lo.2005.50.4.1172

Lesser, M. P. (2006). Oxidative stress in marine environments: biochemistry and physiological ecology. Annu. Rev. Physiol. 68, 253-278. doi: 10.1146/ annurev.physiol.68.040104.110001

Liu, W., Au, D. W. T., Anderson, D. M., Lam, P. K. S., and Wu, R. S. S. (2007). Effects of nutrients, salinity, $\mathrm{pH}$ and light:dark cycle on the production of reactive oxygen species in the alga Chattonella marina. J. Exp. Mar. Biol. Ecol. 346, 76-86. doi: 10.1016/j.jembe.2007.03.007

Mardones, J. I., Dorantes-Aranda, J. J., Nichols, P. D., and Hallegraeff, G. M. (2015). Fish gill damage by the dinoflagellate Alexandrium catenella from Chilean fjords: synergistic action of ROS and PUFA. Harmful Algae 49, 40-49. doi: 10.1016/j.hal.2015.09.001

Marshall, J.-A., De Salas, M., Oda, T., and Hallegraeff, G. (2005a). Superoxide production by marine microalgae: I. Survey of 37 species from 6 classes. Mar. Biol. 147, 553-540. doi: 10.1007/s00227-005-1596-7

Marshall, J.-A., De Salas, M., Oda, T., and Hallegraeff, G. (2005b). Superoxide production by marine microalgae II. Towards understanding ecological 
consequences and possible functions. Mar. Biol. 147, 533-540. doi: 10.1007/ s00227-005-1597-6

Marshall, J.-A., Hovenden, M., Oda, T., and Hallegraeff, G. M. (2002). Photosynthesis does influence superoxide production in the ichthyotoxic alga Chattonella marina (Raphidophyceae). J. Plankton Res. 24, 1231-1236. doi: 10.1093/plankt/24.11.1231

Marshall, J.-A., Nichols, P. D., Hamilton, B., Lewis, R. J., and Hallegraeff, G. M. (2003). Ichthyotoxicity of Chattonella marina (Raphidophyceae) to damselfish (Acanthochromis polycanthus): the synergistic role of reactive oxygen species and free fatty acids. Harmful Algae 2, 273-281. doi: 10.1016/S15689883(03)00046-5

Martel, C. M. (2009). Conceptual bases for prey biorecognition and feeding selectivity in the microplanktonic marine phagotroph Oxyrrhis marina. Microb. Ecol. 57, 589-597. doi: 10.1007/s00248-008-9421-8

Milne, A., Davey, M. S., Worsfold, P. J., Achterberg, E. P., and Taylor, A. R. (2009). Real-time detection of reactive oxygen species generation by marine phytoplankton using flow injection-chemiluminescence. Limnol. Oceanogr. Methods 7, 706-715. doi: 10.4319/lom.2009.7.706

Mittler, R., Vanderauwera, S., Suzuki, N., Miller, G., Tognetti, V. B., Vandepoele, K., et al. (2011). ROS signaling: the new wave? Trends Plant Sci. 16, 300-309. doi: $10.1016 /$ j.tplants.2011.03.007

Morris, J. J., Johnson, Z. I., Szul, M. J., Keller, M., and Zinser, E. R. (2011). Dependence of the cyanobacterium Prochlorococcus on hydrogen peroxide scavenging microbes for growth at the ocean's surface. PLoS One 6:e16805. doi: 10.1371/journal.pone.0016805

Oda, T., Ishimatsu, A., Shimada, M., Takeshita, S., and Muramatsu, T. (1992). Oxygen-radical-mediated toxic effects of the red tide flagellate Chattonella marina on Vibrio alginolyticus. Mar. Biol. 112, 505-509. doi: 10.1007/ BF00356297

Oda, T., Moritomi, J., Kawano, I., Hamaguchi, S., Ishimatsu, A., and Muramatsu, T. (1995). Catalase- and superoxide dismutase-induced morphological changes and growth inhibition in the red tide phytoplankton Chattonella marina. Biosci. Biotechnol. Biochem. 59, 2044-2048.

Oda, T., Nakamura, A., Shikayama, M., Kawano, I., Ishimatsu, A., and Muramatsu, T. (1997). Generation of reactive oxygen species by raphidophycean phytoplankton. Biosci. Biotechnol. Biochem. 61, 1658-1662.

Oshikawa, J., Urao, N., Kim, H. W., Kaplan, N., Razvi, M., Mckinney, R., et al. (2010). Extracellular SOD-derived $\mathrm{H}_{2} \mathrm{O}_{2}$ promotes VEGF signaling in caveolae/ lipid rafts and post-ischemic angiogenesis in mice. PLoS One 5:e10189. doi: 10.1371/journal.pone.0010189

Paasche, E. (2002). A review of the coccolithophorid Emiliania huxleyi (Prymnesiophyceae), with particular reference to growth, coccolith formation, and calcification-photosynthesis interactions (Phycological Reviews 20). Phycologia 40, 503-529. doi: 10.2216/i0031-8884-40-6-503.1

Palenik, B., Zafiriou, O. C., and Morel, F. M. M. (1987). Hydrogen peroxide production by a marine phytoplankter 1. Limnol. Oceanogr. 32, 1365-1369. doi: $10.4319 /$ lo.1987.32.6.1365

Portune, K. J., Cary, S. C., and Warner, M. E. (2010). Antioxidant enzyme response and reactive oxygen species production in marine raphidophytes. J. Phycol. 46, 1161-1171. doi: 10.1111/j.1529-8817.2010.00906.x

Poulson-Ellestad, K. L., Harvey, E. L., Johnson, M. D., and Mincer, T. J. (2016). Evidence for strain-specific exometabolomic responses of the coccolithophore Emiliania huxleyi to grazing by the dinoflagellate Oxyrrhis marina. Front. Mar. Sci. 3:1. doi: 10.3389/fmars.2016.00001

Roe, K. L., and Barbeau, K. A. (2014). Uptake mechanisms for inorganic iron and ferric citrate in Trichodesmium erythraeum IMS101. Metallomics 6, 2042-2051. doi: 10.1039/c4mt00026a

Rose, A. L. (2012). The influence of extracellular superoxide on iron redox chemistry and bioavailability to aquatic microorganisms. Front. Microbiol. 3:124. doi: $10.3389 /$ fmicb.2012.00124

Rose, A. L., Salmon, T. P., Lukondeh, T., Neilan, B. A., and Waite, T. D. (2005). Use of superoxide as an electron shuttle for iron acquisition by the marine cyanobacterium Lyngbya majuscula. Environ. Sci. Technol. 39, 3708-3715. doi: 10.1021/es048766c

Rose, A. L., Webb, E. A., Waite, T. D., and Moffett, J. W. (2008). Measurement and implications of nonphotochemically generated superoxide in the equatorial Pacific Ocean. Environ. Sci. Technol. 42, 2387-2393. doi: 10.1021/es7024609

Rossi, D. C. P., Gleason, J. E., Sanchez, H., Schatzman, S. S., Culbertson, E. M., Johnson, C. J., et al. (2017). Candida albicans FRE8 encodes a member of the NADPH oxidase family that produces a burst of ROS during fungal morphogenesis. PLoS Pathog. 13:e1006763. doi: 10.1371/journal.ppat.1006763

Saragosti, E., Tchernov, D., Katsir, A., and Shaked, Y. (2010). Extracellular production and degradation of superoxide in the coral Stylophora pistillata and cultured Symbiodinium. PLoS One 5:e12508. doi: 10.1371/journal. pone. 0012508

Saran, M. (2003). To what end does nature produce superoxide? NADPH oxidase as an autocrine modifier of membrane phospholipids generating paracrine lipid messengers. Free Radic. Res. 37, 1045-1059. doi: 10.1080/10715760310001594631

Schneider, R. J., Roe, K. L., Hansel, C. M., and Voelker, B. M. (2016). Specieslevel variability in extracellular production rates of reactive oxygen species by diatoms. Front. Chem. 4:5. doi: 10.3389/fchem.2016.00005

Shapiguzov, A., Vainonen, J., Wrzaczek, M., and Kangasjärvi, J. (2012). ROStalk - how the apoplast, the chloroplast, and the nucleus get the message through. Front. Plant Sci. 3. doi: 10.3389/fpls.2012.00292

Strom, S. L., and Bright, K. J. (2009). Inter-strain differences in nitrogen use by the coccolithophore Emiliania huxleyi, and consequences for predation by a planktonic ciliate. Harmful Algae 8, 811-816. doi: 10.1016/j.hal.2007.10.005

Strom, S., Wolfe, G., Holmes, J., Stecher, H., Shimeneck, C., Lambert, S., et al. (2003). Chemical defense in the microplankton I: feeding and growth rates of heterotrophic protists on the DMS-producing phytoplankter Emiliania huxleyi. Limnol. Oceanogr. 48, 217-229. doi: 10.4319/lo.2003.48.1.0217

Suggett, D. J., Le Floc'h, E., Harris, G. N., Leonardos, N., and Geider, R. J. (2007). Different strategies of photoacclimation by two strains of Emiliania huxleyi (Haptophyta). J. Phycol. 43, 1209-1222. doi: 10.1111/j.15298817.2007.00406.x

Sunda, W. G., and Hardison, D. R. (2010). Evolutionary tradeoffs among nutrient acquisition, cell size, and grazing defense in marine phytoplankton promote ecosystem stability. Mar. Ecol. Prog. Ser. 401, 63-76. doi: 10.3354/meps08390

Tanaka, K., Yoshimatsu, S., and Shimada, M. (1992). Generation of superoxide anions by Chattonella antiqua: possible causes for fish death caused by 'Red Tide. Experientia 48, 888-890. doi: 10.1007/BF02118427

Vardi, A., Haramaty, L., Van Mooy, B. A., Fredricks, H. F., Kimmance, S. A., Larsen, A., et al. (2012). Host-virus dynamics and subcellular controls of cell fate in a natural coccolithophore population. Proc. Natl. Acad. Sci. 109, 19327-19332. doi: 10.1073/pnas.1208895109

Westbroek, P., Young, J. R., and Linschooten, K. (1989). Coccolith production (Biomineralization) in the marine alga Emiliania huxleyi. J. Protozool. 36, 368-373. doi: 10.1111/j.1550-7408.1989.tb05528.x

Wuttig, K., Heller, M. I., and Croot, P. L. (2013). Reactivity of inorganic Mn and $\mathrm{Mn}$ desferrioxamine $\mathrm{B}$ with $\mathrm{O}_{2}, \mathrm{O}_{2}^{-}$, and $\mathrm{H}_{2} \mathrm{O}_{2}$ in seawater. Environ. Sci. Technol. 47, 10257-10265. doi: 10.1021/es4016603

Yang, C. Z., Albright, L. J., and Yousif, A. N. (1995). Oxygen-radical-mediated effects of the toxic phytoplankter heterosigma-carterae on juvenile rainbowtrout Oncorhynchus mykiss. Dis. Aquat. Org. 23, 101-108. doi: 10.3354/ dao023101

Zhang, T., Diaz, J. M., Brighi, C., Parsons, R. J., Mcnally, S., Apprill, A., et al. (2016a). Dark production of extracellular superoxide by the coral Porites astreoides and representative symbionts. Front. Mar. Sci. 3:232. doi: 10.3389/ fmars.2016.00232

Zhang, T., Hansel, C. M., Voelker, B. M., and Lamborg, C. H. (2016b). Extensive dark biological production of reactive oxygen species in brackish and freshwater ponds. Environ. Sci. Technol. 50, 2983-2993. doi: 10.1021/acs. est.5b03906

Zinser, E. R. (2018). The microbial contribution to reactive oxygen species dynamics in marine ecosystems. Environ. Microbiol. Rep. 10, 412-427. doi: $10.1111 / 1758-2229.12626$

Conflict of Interest Statement: The authors declare that the research was conducted in the absence of any commercial or financial relationships that could be construed as a potential conflict of interest.

Copyright (c) 2019 Plummer, Taylor, Harvey, Hansel and Diaz. This is an open-access article distributed under the terms of the Creative Commons Attribution License (CC BY). The use, distribution or reproduction in other forums is permitted, provided the original author(s) and the copyright owner(s) are credited and that the original publication in this journal is cited, in accordance with accepted academic practice. No use, distribution or reproduction is permitted which does not comply with these terms. 